УДК 378.016:811.111]:821.111 Лью̈с

\title{
МЕТОДИКА НАВЧАННЯ ЧИТАННЯ АНГЛЙИСЬОЮ МОВОЮ $З$ ВИКОРИСТАННЯМ АВТЕНТИЧНИХ ТЕКСТІВ ДЛЯ СТУДЕНТІВ СПЕЦАЛЬНИХ ФАКУЛЬТЕТІВ (на матеріалі роману К. Льюїса "Хроніки Нарнії: Лев, чаклунка і стара шафа”)
}

\section{Юлія Словська}

\author{
Криворізький державний педагогічний університет \\ Kryvyi Rih State Pedagogical University \\ nр. Гагаріна, 54, Кривий Ріг, 50086, Україна \\ julia.yelovska@gmail.com
}

Словська Ю. Методика навчання читання англійською мовою з використанням автентичних текстів для студентів спеціальних факультетів (на матеріалі роману К. Льюїса “Хроніки Нарнії: Лев, чаклунка і стара шафа”)

У статті проаналізовано сучасні підходи до навчання читання іноземною мовою, зокрема англійською. Розглянуто особливості й етапи роботи 3 автентичними текстами, які нині представлені в розвідках вітчизняних і зарубіжних мовознавців. Запропоновано комплекс завдань для формування мовної й мовленнєвої компетентності студентів спеціальних факультетів із використання автентичних текстів на базі оригінального роману К. Льюїса "Хроніки Нарнії: Лев, чаклунка і стара шафа”.

Ключові слова: навчання читання, автентичний текст, дотекстовий етап, текстовий етап, післятекстовий етап.

Еловская Ю. Методика обучения чтению на английском языке с использованием аутентичных текстов для студентов специальных факультетов (на материале романа К. Льюиса “Хроники Нарнии: Лев, колдунья и волшебный шкаф”)

В статье проанализированы современные подходы к обучению чтению на иностранном языке (английском) с использованием аутентичных текстов. Рассмотрены особенности и этапы работы с аутентичными текстами, представленные в отечественном и зарубежном языкознании. Разработан комплекс упражнений для формирования языковой и речевой компетентности студентов специальных факультетов с использованием аутентичных текстов, на базе неадаптированного романа К. Льюиса "Хроники Нарнии: Лев, колдунья и волшебный шкаф”.

Ключевые слова: обучение чтению, аутентичный текст, дотекстовый этап, текстовый этап, послетекстовый этап. 
Yelovska Yu. Methods of teaching reading using English authentic texts for students of special faculties (on the material of the novel "Chronicles of Narnia" by C. Lewis)

This paper deals with the modern approaches in teaching reading skills though authentic texts. It analyzes recent research covering the problem of using authentic materials in teaching foreign languages, English in particular. It also focuses on identifying the peculiarities of selecting authentic texts and its advantages of using them in the class. The paper sums up the key stages of teaching reading (pre-reading, while-reading and post-reading) as well. Moreover, this paper presents the set of tasks based on the fantastic novel "The Chronicles of Narnia: the Lion, the Witch and the Wardrobe" by C. S. Lewis. The choice of this fantastic novel as the main source of an authentic text is explained by the fact that this work contains numerous idiomatic expressions that reveal the cultural heritage and contribute to the acquisition of linguistic and cultural information. The work contains a great variety of descriptive parts that correspond to the thematic blocks of the academic course "Practical English Course of Second Language (English)". It expands and consolidates the active vocabulary of students. The novel also represents an interesting interpretation of many religious and moral-ethical aspects of life, depicted on the background of fantastic events, which have a great impact on training future language teachers. These exercises are built according to the main stages of working with the authentic texts including pre-reading, while-reading and post-reading activities. These tasks focus on not only developing communicative skills, simultaneously training vocabulary and grammar, but also cover moral aspects of upbringing. They can be successfully applied as the part of an optional home reading course in terms of teaching the academic course "Practical course of the main language (English)".

Key words: teaching reading, authentic text, pre-reading, while reading, post-reading.

Постановка проблеми та іiї зв'язок 3 важливими науковими завданнями. Глобалізаційні й інтеграційні процеси, що панують в українському суспільстві, сприяють активізації міжнародних відносин і вимагають від сучасної людини знання й володіння іноземною мовою, передусім англійською. Новітні світові тенденції, зокрема рекомендації Ради Європи, ставлять перед закладами освіти завдання не лише готувати висококваліфікованих фахівців різних спеціальностей, а й створювати умови для ефективного формування їхньої соціокультурної компетенції, яка передбачає набуття мовних i мовленнєвих навичок, знання лінгвокраїнознавчої та соціокультурної інформації для здійснення успішної міжкультурної комунікації. 
Поряд iз вивченням фахових дисциплін важливим напрямом у підготовці спеціалістів у вищій школі $є$ вивчення іноземної мови (насамперед, англійської). Навчання іноземної мови передбачає оволодіння студентами чотирма основними видами діяльності, необхідними для їхньої іншомовної комунікативної самореалізації, а саме: читання, аудіювання, говоріння, письмо.

Метою запропонованої статті $\epsilon$ аналіз сучасних підходів до навчання іноземної мови, зокрема англійської, присвячених розвиткові навичок читання 3 використанням автентичних текстів, та представлення низки вправ, побудованих на матеріалі оригінального твору К. Льюїса "Хроніки Нарнії: Лев, чаклунка $\mathrm{i}$ стара шафа", для формування комунікативної компетенції студентів спеціальних факультетів. Задля цього розв'язували такі завдання, як-от: 1) проаналізувати сучасні наукові розвідки 3 вивчення особливостей використання автентичних текстів у формуванні навичок читання; 2) розглянути етапи роботи 3 автентичними текстами на заняттях 3 іноземної (англійської) мови; 3) створити комплекс вправ на основі автентичного художнього твору (роман К. Льюїса “Хроніки Нарнії: Лев, біла відьма і шафа").

Аналіз останніх досліджень та публікацій. Читання, як відомо, є одним із важливих видів мовленнєвої діяльності людини. Н. Гриняєва та І. Зуєва зазначають, що читання текстів іноземною мовою розвиває критичне мислення студентів, сприяє усвідомленню особливостей побудови мовних систем в іноземній і рідній мовах, збагачує їхній світогляд [Hryniaieva / Гриняєва 2018: 31]. Г. Борецька визначає компетентність у читанні як “здатність читати автентичні тексти різних жанрів $\mathrm{i}$ видів із різним рівнем розуміння змісту в умовах опосередкованого спілкування" [Boretska / Борецька 2012 : 18]. Під поняттям “автентичний текст" розуміємо оригінальний зв'язний текст будь-якого жанру (художній, науковий, публіцистичний тощо), створений носієм тієї чи тієї мови. Проблема залучення автентичних текстів у процес вивчення іноземної мови $є$ предметом зацікавлення багатьох вітчизняних і зарубіжних науковців та широко представлена у їхніх працях 
(Ю. Андруша, С. Берардо, Г. Борецька, Ю. Веклич, М. Гілмор, Т. Гужва, Н. Гриняєва, О. Киян, Т. Кравченко, Т. Полонська, Н. Савінова, А. Марзбан та ін.).

Дослідники сходяться на тому, що найголовнішою перевагою використання автентичних текстів на заняттях з іноземної мови є те, що викладач має вільний простір для вибору таких матеріалів: від художніх творів, написаних мовою оригіналу, чи перекладів, представлених мовою навчання (наприклад, англійською), до текстів реклам, оголошень, публіцистичних статей із газет, журналів та інтернет-видань, що дає змогу підібрати необхідний матеріал відповідно до рівня знань студентів. Ю. Андруша акцентує на тому, що на відміну від адаптованих автентичні тексти занурюють студентів у реальні комунікативні ситуації, властиві іншомовному простору, зокрема англійському [Andrushcha/ Андрюша 2018: 300]. С. Берардо зауважує, що автентичні матеріали сприяють позитивній мотивації студентів, представляють їхній увазі культурний інформаційний пласт для подальшого осмислення й розуміння, мотивують викладачів до реалізації творчих підходів у процесі навчання [Berado 2006 : 64].

Незважаючи на наведені вище переваги використання автентичних текстів, варто також ураховувати низку особливостей добору автентичних матеріалів, які застосовуються при вивченні іноземної мови. К. Полонська слушно наголошує на відповідності змісту автентичних текстів темам, що вивчаються, їхній соціокультурній значущості та морально-етичним аспектам [Polonska / Полонська 2016 : 381]. Г. Борецька та С. Берардо підкреслюють, що такі матеріали мають бути цікавим, мати пізнавальну цінність, відповідати віковим особливостям і рівню мовної підготовки студентів [Boretska / Борецька 2012 : 23; Berardo 2006 : 62].

Виклад основного матеріалу дослідження. Важливого значення використання автентичних текстів на заняттях з іноземної мови (англійської) набуває при підготовці майбутніх педагогів-філологів. Такий підхід сприяє не лише активному засвоєнню різноманітних лексичних сполучень і граматичних структур, розвитку мовного спостереження за динамікою та 
видозмінами, що відбуваються в мові 3 плином часу, а й навичкам критичного мислення й аналітичного читання.

Серед розмаїття жанрів автентичних текстів найбільш оптимальним у межах підготовки майбутніх вчителів англійської мови вважаємо художні твори англійських та американських письменників. У пропонованій розвідці твір "Хроніки Нарнії: Лев, чаклунка і стара шафа" К. Льюїса розглядається в межах академічної дисципліни "Практичний курс англійської мови” для студентів філологічних факультетів. Вибір саме цього фантастичного роману як основного джерела автентичного тексту пояснюємо тим, що твір містить ілюстрації граматичних структур англійської мови, які зазнали певних трансформацій (наприклад, уживання форм множини іменників: авторське hoofs замість сучасного hooves), а також численні ідіоматичні вирази, що розкривають культурне багатство англійської мови, сприяють засвоєнню лінгвокультурної інформації. У творі фіксуємо достатню кількість описових фрагментів, які відповідають тематичним блокам академічної дисципліни "Практичний курс англійської мови” (описи будинку або печери, погодних умов, одягу, зовнішності, характеру героїв тощо), розширюють і закріплюють активний словниковий запас студентів-філологів. Зважаючи на історію виникнення роману й особистісні переконання К. Льюїса, твір містить цікаву інтерпретацію багатьох релігійних і моральноетичних аспектів життя, зображених на тлі фантастичних подій, що виконує виховну роль у підготовці майбутніх учителівмовників. Наявність перекладів українською мовою сприяє розвитку навичок порівняльного аналізу твору, а його екранізація підвищує мотивацію до читання задля встановлення відповідності змісту книги й сюжету кінематографічної стрічки.

Формування навичок читання через вивчення будь-якого тексту, автентичного зокрема, передбачає врахування трьох основних етапів: дотекстового (pre-reading), текстового (whilereading), післятекстового (post-reading). Окрім того, звертаємо увагу на те, що автентичні художні твори дають змогу викладачеві використовувати різні підходи читання у формуванні навичок детального читання для пошуку детальної 
інформації (close reading), наскрізного читання для розуміння основного тексту (skim reading), вибіркового читання 3 вилученням необхідної інформації (scan reading).

Завданням викладача на дотекстовому етапі є заохочення студентів до прочитання обраного автентичного твору. Добірка цікавих фактів 3 життя автора та історії створення роману у формі відкритих запитань, які можна виносити на самостійне опрацювання 3 подальшим монологічним мовленням студентів (наприклад: Why was Clive Staples Lewis called Jack?; What was the reason of writing the novel and how was it connected with J. Tolkien? Who was this novel devoted to?) сприяють пробудженню інтересу студентів до твору. Наочна демонстрація обгортки книги із переліком запитань (How does the title of the book correspond to its further content? Give your ideas what is this book about. Can you guess its probable plot?) мотивує студентів до висування здогадок щодо назви твору й активізації їхньої уяви щодо розгортання подій у ньому.

Не менш важливим на дотекстовому етапі, на нашу думку, $\epsilon$ часткове усунення труднощів, пов'язаних із вимовою окремих мовних одиниць або імен героїв й опрацювання незнайомої ідіоматичної лексики. Так, наприклад, перед читанням твору вважаємо необхідним подавати до кожної 3 частин короткий лексичний коментар, який містить словник із тлумаченням складних лінгвоодиниць. Зауважимо, що такі коментарі сприяють кращому розумінню твору й підвищують мотивацію до читання оригінального іншомовного тексту, який стає більш зрозумілим i легким для сприйняття. Серед завдань дотекстового етапу пропонуємо використання низки вправ для закріплення нової лексики, яка може викликати труднощі у процесі читання твору (наприклад: match the words and its definition; find the synonyms / antonyms of the following words); висловлення думок щодо назви частини й передбачуваного розгортання сюжету, що водночас активізує прогностичні навички та спонукає студентів до здійснення мовленнєвої діяльності (наприклад: Read the title of the chapter. How do you think what can this chapter tell about? Imagine that you are the writer of this story, what would you write in this chapter?). 
Текстовий етап передбачає безпосереднє занурення в текст твору, перевірку розуміння студентами його змісту та активне використання отриманої інформації. На цьому етапі передбачено використання завдань, побудованих за пошуковим принципом, а саме: вправи 3 переліком запитань, на які треба знайти відповіді в тексті твору; низку речень із загубленим початком / кінцем, які необхідно відтворити; ряд реплік і героїв, які треба поєднати; описи окремих ситуацій чи героїв; граматичні завдання на засвоєння певних граматичних правил. Зауважимо, що запропоновані пошукові вправи покликані передусім розвивати у студентів навички close reading та scan reading, акцентувати увагу на деталях твору.

Наведемо приклади вправ текстового етапу, розроблених для 2-ї і 3-ї частин твору К. Льюїса "Хроніки Нарнії: Лев, чаклунка і стара шафа":

\section{Finish the sentences:}

1. ... where we are now; all that lies between the lamp-post and the great castle...

2. It was a little, dry, clean cave of reddish stone...

3. There was a nice brown egg, lightly boiled, for each of them, ...

4. You ought to be ashamed of yourself, ....

5. Always winter and never.....

6. "We must go as quietly as we can," said Mr. Tumnus. "The whole wood...."

7. The journey back was not at all like the journey to the Faun's cave; they stole along as quickly as they could, ....

8. Then be off home as quick ....

Match the idioms and corresponding definitions. Find them in the text of the chapter:

\begin{tabular}{|l|l|}
\hline 1) to come out & a) not say a word \\
2) to go over & b) employed by \\
3) under one's thumb & c) to go away; to leave \\
4) to keep on & d) continue to do something \\
5) to hand over to & e) to start feel happier, more cheerful \\
6) in the pay & f) only for or because of one person \\
7) to be off & g) pass something to someone, after \\
\hline
\end{tabular}




\begin{tabular}{|l|l|}
\hline 8) on one's account & being asked or told to do this \\
9) without speaking a word & h) to appear \\
10) to cheer up & i) to examine or look at something in \\
a careful or detailed way \\
j) completely under someone's \\
influence or control
\end{tabular}

\section{Who said that:}

1. What on earth are you talking about, Lucy?" asked ....

2. "Poor old Lu, hiding and nobody noticed!" ....

3. "Don't be silly, Lucy," said ...

4. "It's - it's a magic wardrobe. There's a wood inside it, and it's snowing....

5. “That's going a bit far. You've had your joke. Hadn't you better drop it now?" ....

6. "Thank goodness," said ...., "the door must have swung open of its own accord."

7. "She's angry about all the things I've been saying lately," thought ....

8. "I say, Lu! I'm sorry I didn't believe you. I see now you were right all along." ...

9. "And what, pray, are you?" said the ....

10. "Please, your Majesty," said ..., "I don't know what you mean".

Find in the text the description of:

- the Witch

- the dwarf

- the sledge and the reindeer

- the weather in Narnia

True or false:

1. It was just after dinner when I went into the wardrobe, and I've been away for hours and hours, and had tea, and all sorts of things have happened.

2. Then everyone looked in and pulled the coats apart; and they all saw - Lucy herself saw a perfectly ordinary bedroom.

3. But Lucy was a very cunning girl and she knew that she was really in the right. 
4. That day, when it came to the afternoon and the weather was perfect and they decided to play cricket.

5. Overhead there was bright blue sky, the sort of sky one sees on a fine winter day in the morning.

6. And though Edmund did not like to admit that he had been wrong, he also liked being alone in this strange, cold, quiet place.

7. The reindeer were bigger than Shetland ponies.

8. On a much higher seat in the middle of the sledge sat a very different person - a great gentleman, taller than any man that Edmund had ever seen.

9. In the hot air the breath coming out of their nostrils looked like smoke.

10. "I don't know what you mean. I'm at university - at least I was it's the holidays now."

Післятекстовий етап передбачає контроль розуміння тексту 3 його подальшим обговоренням. На цьому етапі доцільно використовувати низку запитань, які дають змогу студентам висловити власну думку щодо подій у творі, проаналізувати зв'язок мовних конструкцій, вжитих автором для створення відповідного враження читача, складання плану твору, написання коротких анотацій до кожної 3 частин, продукування переказу сюжету від особи певного героя. Такі завдання сприяють створенню цілісної картинки прочитаного, допомагають відтворити логічний зв'язок подій у творі, розвивають навички аналізу, синтезу й узагальнення.

Наведемо приклади післятекствих вправ, розроблених для 4-ї частини твору:

Describe the Witch according to Edmund and Lucy's opinion. Give your reasons and find sentences in the text, proving your ideas.

\begin{tabular}{|l|l|}
\hline \multicolumn{2}{|c|}{ The Witch } \\
\hline Edmund & Lucy \\
\hline & \\
\hline
\end{tabular}




\section{Fill in the table to restore the events of the chapter and write its summary}

\begin{tabular}{|l|l|}
\hline When & Describe when the action starts. \\
\hline Where & $\begin{array}{l}\text { Describe where the action takes } \\
\text { place. }\end{array}$ \\
\hline Who & Identify the main characters. \\
\hline What & $\begin{array}{l}\text { What actions are described in the } \\
\text { chapter? }\end{array}$ \\
\hline Key point & $\begin{array}{l}\text { Identify the key point (climax) of the } \\
\text { chapter. }\end{array}$ \\
\hline The result & What does the chapter end with? \\
\hline
\end{tabular}

\section{Висновки та перспективи подальших наукових} розвідок. Використання автентичних текстів позитивно впливає на розвиток іншомовної компетенції студентів-філологів. Застосування англомовних художніх творів як взірців автентичності з урахуванням низки особливостей $є$ запорукою успішного формування навичок читання на заняттях з іноземної мови. Навчання читання на базі автентичних творів передбачає виконання дотекстових, текстових і післятекстових завдань, які сприяють кращому розумінню й засвоєнню прочитаного. Комплекс запропонованих вправ на матеріалі роману К. Льюїса "Хроніки Нарнії: Лев, чаклунка і стара шафа" активізує пізнавальні й комунікативні навички, закріплює набуті граматичні й лексичні знання майбутніх вчителів-мовників. Подальші наукові пошуки вбачаємо у створенні комплексів вправ для навчання аудіювання 3 використанням автентичних відео- та аудіоматеріалів.

\section{Література}

1. Андруща Ю. С. Роль і особливості використання автентичних текстів в умовах мультилінгвального навчання англійської мови. Міжкультурна ц̆ міжмовна комунікація: проблеми, питання, вирішення. 2018. № 12. С. 297-305.

2. Борецька Г. Е. Методика формування іншомовної компетентності у читанні. Іноземні мови. 2012. № 3 (71). С. 18-27.

3. Гриняєва Н. М., Зуєва І. В. Читання як засіб формування мовленнєвої компетенції при вивченні дисципліни "Іноземна мова за проф. спрямуванням". Science Review. 2018. № 2 (9). C. 27-33. 
4. Полонська Т. К. Автентичний текст як основний структурний компонент навчальних посібників елективних курсів 3 іноземних мов для учнів профільної школи (на прикладі навчального посібника "Culture and Art of Great Britain”). Проблеми сучасного підручника. 2016. Вип. 17. С. 377-388.

5. Berardo S. The use of authentic materials in the teaching of reading. The Reading Matrix. 2006. No. 6 (2). P. 60-69.

6. Marzban A. The Effect of Authentic Texts on Motivation and Reading Comprehension of EFL Students at Intermediate Level of Proficiency. Theory and Practice in Language Studies. 2015. Vol. 5 No. 1. P. 85-91.

\section{References}

1. Andrushcha Yu.S. Rol i osoblyvosti vykorystannya avtentychnyh tekstiv v umovah multylinhvalnoho navchannia anhliyskoi movy. Mizhkulturna y mizhmovna komunikatsiia: problemy, pytannia, vyrishennia. 2018. № 12. S. 297-305.

2. Boretska H. E. Metodyka formuvannia inshomovnoi kompetentnosti u chytanni. Inozemni movy. 2012. № 3 (71). S. 18-27.

3. Hryniaieva N. M., Zuieva I. V. Chytannia yak zasib formuvannia movlennyevoi kompetentsii pry vyvchenni dystsypliny "Inozemna mova za prof. spriamuvanniam”. Science Review. 2018. № 2 (9). S. 27-33.

4. Polonska T.K. Avtentychnyi tekst yak osnovnyi strukturnyi komponent navchalnyh posibnykiv elektyvnyh kursiv z inozemnyh mov dlia uchniv profilnoi shkoly (na prykladi navchalnoho posibnyka "Culture and Art of Great Britain"). Problemy suchasnoho pidruchnyka. 2016. Vyp. 17. S. 377-388.

5 . Berardo $\mathrm{S}$. The use of authentic materials in the teaching of reading. The Reading Matrix. 2006. No. 6 (2). P. 60-69.

6. Marzban A. The Effect of Authentic Texts on Motivation and Reading Comprehension of EFL Students at Intermediate Level of Proficiency. Theory and Practice in Language Studies. 2015. Vol. 5 No. 1. P. 85-91.

Стаття надійшла до редакиії 06.09.2019 р.

Прийнята до друку 19.11.2019 р. 